Syntax Fusion : Jurnal Nasional Indonesia

P-ISSN: $x x x x-x x x x$

E-ISSN : $x x x x-x x x x$

Vol. 1, No. 2, Februari 2021

\title{
ULUL ALBAB SEBAGAI PANDANGAN HIDUP KADER HIMA PERSIS (STUDI FENOMENOLOGI PEMAHAMAN KADER HIMA PERSIS STAI PERSIS BANDUNG TERHADAP AYAT-AYAT ULUL ALBAB)
}

\author{
Amirul Muttaqien \\ Stai Persis Bandung \\ E-mail: Arulmuttaqien84@gmail.com
}

\begin{abstract}
Abstrak
Hima Persis merupakan organisasi mahasiswa eksternal kampus yang berada di bawah naungan Persatuan Islam. Organisasi modern Persis di lingkungan mahasiswa menjadi media transformatif gagasan-gagasan Persatuan Islam di kampus-kampus serta dapat mengembangakan produk produk intelektual kampus dalam upaya menunjang perjuangan Persis dimasa yang akan datang sesuai dengan tantangan pemikiaran yang lebih bersifat ilmiah dan intelektualis. Demi mewujudkan cita-cita dan harapan yang terdapat pada substansi mahasiswa dan organisasi induknya Persatuan Islam, maka Hima Persis mengambil ayat-ayat Ulul Albab sebagai falsafah dan pandangan hidup dalam gerakannya. Penelitian ini menggunakan metode deskriptif kualitatif, karena metode ini dipandang lebih mampu menangkap berbagai informasi dengan kejelasan deskripsi yang lebih teliti dan penuh makna. Permasalahan yang diteliti dalam skripsi ini melihat bagaimana pemahaman dan implementasi indikator Ulul Albab kader Hima Persis STAI Persis Bandung dengan melakukan wawancara dan observasi untuk menjawab pertanyaan rumusan masalah sebagai berikut Pada penelitian kali ini dapat disimpulkan bahwa pemahaman kader Hima Persis STAI Persis Bandung masih jauh untuk dikatakan paham secara sempurna. Adapun implementasi dari ayat-ayat Ulul Albab masih belum juga mencerminkan ciri-ciri Ulul Albab.
\end{abstract}

Kata Kunci: Hima Persis, Ulul Alab, Persatuan Islam

\section{Pendahuluan}

Mahasiswa sejak kemunculannya seringkali diidentifikasi sebagai kaum menengah (Middle Class). Kaum tersebut merupakan kaum yang memiliki kedekatan yang tinggi dengan masyarakat kecil dan memiliki nalar kritis terhadap pemerintah selaku pemangku kebijakan. Istilah 'mahasiswa' terdiri dari dua kata 'maha' dan 'siswa'. 'Maha' dalam KBBI artinya besar, teramat, atau sesuatu yang menunjukan kemewahan lebih dari biasa dan 'siswa' merupakan seseorang yang tengah berada dalam proses belajar. Mahasiswa 
kemudian memiliki makna lain dalam perkembangan selanjutnya yaitu Agent of Change (Agen Perubahan) dan Agent of Social Control (Agen Kontrol Sosial). Dengan penyematan identitas itu mahasiswa merupakan kekuatan utama dalam masyarakat untuk melaksanakan perubahan-perubahan yang mengutamakan kepentingan rakyat. (Permana, 2017)

Dalam perkembangannya, gerakan mahasiswa semakin menunjukkan taringnya. Di Indonesia gerakan mahasiswa telah memperlihatkan eksistensi geraknya dari mulai 1908 dimana Ratu Wilhelmina, penguasa pemerintahan Belanda, mengumumkan kebijakan politik etis. Yakni bentuk politik yang didasarkan pada balas budi pemerintahan Belanda kepada bangsa-bangsa yang dijajahnya. Hal tersebut menjadi cikal bakal dari lahirnya gerakan kaum terpelajar dari Boedi Oetomo. Disusul dengan keikutsertaannya dalam penurunan rezim orde lama pada tahun 1965, juga penurunan rezim Soeharto pada orde baru tahun 1998. Keterlibatan mahasiswa dalam gerakan-gerakan tersebut tidak hanya satu atau dua kelompok saja, melainkan kesadaran kolektif yang dibangun pada tiap-tiap organisasi yang dipegangnya. (Permana, 2017)

Pada peristiwa-peristiwa besar diatas terdapat beberapa gerakan mahasiswa yang membawa massa yang cukup banyak dari mulai organisasi mahasiswa Islam hingga nonIslam. Hal tersebut merupakan pencapaian besar dalam sejarah bangsa Indonesia, dimana seluruh masyarakat dengan berbagai level dapat berkumpul dengan kesadaran yang sama bahwa bangsa Indonesia harus tetap utuh.

Cara pandang yang sama ditunjukkan oleh salah satu organisasi mahasiswa Islam, yakni Hima Persis. Hima persis merupakan salah satu gerakan mahasiswa yang berada didalam naungan ormas Persatuan Islam (PERSIS). Berdiri pada tahun 23 September 1996, Hima Persis mencoba ikut serta dalam menyelesaikan persoalan pada rezim orde baru. Namun yang perlu dicatat adalah, berdirinya Hima Persis bukan untuk menambah deretan panjang berdirinya organisasi-organisasi mahasiswa di tengah mainstream yang ada, lebih dari itu berdirinya Hima Persis di tengah kemelut Orde Baru adalah untuk memperkuat ruh pembaharuan yang dibawa oleh organisasi induknya Persis di kalangan mahasiswa. Falsafah gerakan yang diambil oleh Hima Persis dalam gerakannya adalah 16 ayat ulul albab dalam Al Quran, yakni jati diri yang mengintegrasikan iman, ilmu, dan amal sholeh. (Persis, n.d., p. 22)

Menurut Wahbah Zuhayli dalam tafsirnya seseorang yang memiliki ruh Ulul Albab adalah orang yang mampu mengintegrasikan dzikir dan fikir. Dzikir adalah dimensi yang berhubungan dengan Tuhan dan melalui fikir manusia mampu mengkontekstualisasikan ide-ide ketuhanan. Artinya manusia yang memiliki ruh ulul albab memiliki semangat beribadah yang kuat dan kemampuan berpikir yang tajam dalam meninjau realitas. Lebih jauh lagi, konsepsi Ulul Albab dalam paradigma Hima Persis ditafsirkan ke dalam tiga spectrum strategis, yaitu; Imarah al Fikriyah (Kepemimpinan Pemikiran), Taghyir al Siyasi (Perubahan Iklim Politik), dan Taghyir al Ijtimaiyyah (Perubahan Sosial).(Persis, 2018, p. 22)

Selanjutnya Ulul Albab menurut salah satu founding father Hima Persis, Lamlam Pahala adalah sekelompok orang yang memiliki akal kecerdasan, yang senantiasa 
melakukan aktifitas berfikir, mampu memahami berbagai persoalan, dan senantiasa menyingkap misteri dibalik peristiwa kasat mata atau mengungkapkan dimensi terpenting dan hikmah dari sesuatu yang nampak. Adapun personalitas kader Hima Persis tertuang dalam 10 poin; memiliki kecerdasan teologis, tunduk tanpa negosiasi, mawas diri dalam bersikap, pintar tadabbur Al Quran, memiliki hikmah atau intelektualitas tinggi, piawai mengungkap kebijaksanaan syariat, befikir selektif dan kritis, nalar aktual: refleksi dan reaktualisasi sejarah, pro kebenaran meski minoritas, dan terakhir memiliki kecerdasan emosional. (Persis, 2018)

Namun tidak jarang ditemukan beberapa kader Hima Persis yang justru tidak mencerminkan konsepsi ulul albab tersebut. Hal ini terbukti dari beberapa wawancara ringan dan pengamatan sederhana peneliti ia menyatakan bahwa. Peneliti menetapkan indikator sedehana bahwa Ulul Albab sebagaimana yang diungkapkan Wahbah Dzuhaili. Dari hasil wawancara dikemukakan bahwa "Dzikir secara sederhana mengingat dengan pola amalan ibadah mengucapkan kaliat memuja dan memuji Allah dan fikir adalah faham", dan berdasarkan hasil observasi peneliti cukup banyak kader yang dalam solatnya, terkhusus sholat shubuh yang masih telat. Fakta-fakta tersebut mencerminkan adanya kesenjangan antara teori dan praktik.

\section{Metode Penelitian}

Penelitian ini menggunakan metode deskriptif kualitatif, karena metode ini dipandang lebih mampu menangkap berbagai informasi dengan kejelasan deskripsi yang lebih teliti dan penuh makna. Permasalahan yang diteliti yaitu pemahaman dan implementasi Ulul Albab kader Hima Persis STAI Persis Bandung. Penelitian ini menggunakan jenis data kualitatif. Data kualitatif adalah data informasi yang berbentuk kalimat verbal bukan kalimat symbol, angka atau bilangan. Data kualitatif didapat melalui suatu proses menggunakan teknis analisis mendalam dan tidak bisa diperoleh secara langsung.

Analisis data yang digunakan adalah analisis data kualitatif. Analisis data kualitatif adalah upaya yang dilakukan dengan jalan bekerja dengan data, mengorganisasikan data, memilah-milahnya menjadi satuan yang dapat dikelola, mensintesiskan, mencari dan menemukan apa yang penting dan apa yang dipelajari dan memutuskan apa yang dapat diceritakan kepada orang lain. (Moleong \& Surjaman, 1991, p. 248)

\section{Hasil dan Pembahasan}

\section{a. Ulul Albab Sebagai Pandangan Hidup Kader Hima Persis}

Hima Persis merupakan organisasi mahasiswa eksternal kampus yang berada di bawah naungan Persatuan Islam sebagai organisasi induknya. Hima Persis didirikan pada fase kepemimpinan Ustadz Latif Muchtar M.A yang pada saat itu memangku amanat Ketua Umum PP. Persis. Pada awalnya, organisasi modern Persis dilingkungan mahasiswa ini menjadi media transformatif gagasan-gagasan Persatuan Islam di kampuskampus serta dapat mengembangakan produkproduk intelektual kampus dalam upaya 
menunjang perjuangan Persis dimasa yang akan datang sesuai dengan tantangan pemikiaran yang lebih bersifat "ilmiah" dan "intelektualis". Selain faktor kultur akademik yang kental pada diri Ustadz Latif Muchtar, hal terseut juga dimaksudkan untuk menjaga identitas dan keterikatan kader/alumni-alumni Pesantren Persis yang mulai banyak tersebar di berbagai kampus. Berbeda dengan fase Ustadz Abdurrahman yang memang kader-kadernya belum begitu gebyar ter(mem)promosikan di PerguruanPerguruan Tinggi.

Hima Persis diberi hak dan kewajiban, wewenang dan tanggung jawab untuk mengatur dan mengurus sendiri bidang kegiatannya sesuai dengan kewenangan yang diberikan oleh Pimpinan Pusat (IX, 2015, p. 48). Penyematan 'STAI Persis Bandung' berarti menunjukkan lokasi aktivitas atau scoop Hima Persis tersebut. Adapun lokasi STAI Persis Bandung berada di Jalan Ciganitri No.2 Desa Cipagalo, Kecamatan Bojongsoang, Kabupaten Bandung, Jawa Barat.

Hima Persis STAI Persis Bandung, yang secara struktural disebut Pimpinan Komisariat (PK), merupakan level pimpinan paling bawah di bawah level pimpinan daerah (PD) Kabupaten Bandung, di bawah level pimpinan wilayah (PW) Jawa Barat, dan tentunya pimpinan pusat (PP) nasional. (II, 2018, pp. 17-22)

Namun yang menjadi sasaran penelitian pada kali ini adalah seluruh kader Hima Persis STAI Persis Bandung. Penyematan seluruh kader Hima Persis STAI Persis Bandung mengacu pada seluruh kader Hima Persis yang berkuliah di STAI Persis Bandung sekalipun tidak pada struktur level pimpinan komisariat.

\section{b. Pemahaman Kader Hima Persis STAI Persis Bandung terhadap Ayat-ayat Ulul Albab}

Pemaparan penelitian kali ini menyajikan gambaran tentang pemahaman kader Hima Persis STAI Persis Bandung terhadap falsafah gerakannya, yaitu ayat-ayat Ulul Albab. Pemahaman ini diukur dengan beberapa pertanyaan yang meliputi hapalan terhadap ayat-ayat Ulul Albab, kata-kata kunci yang melahirkan makna Ulul Albab dan pengertian Ulul Albab menurut para kader Hima Persis STAI Persis Bandung.

Selanjutnya, dalam mengukur pemahaman yang dimiliki seorang kader diteliti pula seberapa jauh seorang kader mengimplementasikan indikator-indikator Ulul Albab yang telah ditetapkan oleh beberapa mufasir. Gambaran umum penelitian ini adalah dengan mendeskripsikan hasil wawancara dan observasi selama kurun waktu bulan juni hingga juli terhadap beberapa kader Hima Persis STAI Persis Bandung.

Wawancara dilaksanakan dengan menggunakan teknik snowball terhadap 12 orang narasumber kunci yang dilakukan di lingkungan internal Hima Persis STAI Persis Bandung yang bertempat di lokasi Kuliah Kerja Nyata (KKN) para kder Hima Persis tersebut. Narasumber yang berhasil diwawancarai secara intensif dengan beberapa nama, yaitu Hafid, Arman, Asyad, Hawary, Zaim, Saepul, Izal, Fitra, Diki, Anzar, dan Karisma.

Wawancara dilakukan pada satu waktu yakni pada tanggal 18 Juli 2019. Data yang tidak terungkap melalui wawancara, dilengkapi dengan data hasil observasi langsung secara partisipatif yang dilakukan rentang waktu pada bulan April sampai dengan Juli. 
Untuk memperkuat substansi data hasil wawancara dan observasi, maka dilakukanlah penelusuran terhadap dokumen dan arsip yang ada. Semua data hasil penelitian ini diuraikan berdasarkan fokus pertanyaan penelitian sebagai berikut:

Peneliti melakukan teknik wawancara terhadap 12 orang dengan menanyakan terkait hapalan mereka terhadap ke-16 ayat Ulul Albab. Dari 12 orang yang diwawancarai terdapat 2 orang yang tidak hapal satu pun, 1 orang yang hapal satu ayat namun tidak lancar, 4 orang yang hapal satu ayat, dan 5 orang yang hapal dua ayat dari ke-16 ayat Ulul Albab yang ada dalam Al Quran. Diantara 10 orang yang hapal terhadap ayat Ulul Albab, yang paling mendominasi untuk mereka hapal adalah Q.S Ali Imran ayat 7. Diantara narasumber yang diwawancarai, 5 orang diantaranya hanya menyebutkan nama dan ayat dalam surat, 4 orang lupa nama, ayat dan isi dalam ayat tersebut, dan 3 diantaranya mampu membacakan ayat yang dihapalnya.

Menurut narasumber, diketahui bahwa dalam beberapa ayat Ulul Albab, kata kunci Ulul Albab selalu dibangun dengan redaksi "orang-orang yang memperdalam keilmuan" dan pada redaksi akhirnya hanya orang-orang yang berpikirlah yang mampu mengambil pelajaran. Selanjutnya, pada ayat yang lain, Ulul Albab selalu dipersonifikasikan dengan orang yang selalu mengingat Allah di setiap geraknya.

“...Mungkin yang terdapat dalam surat Ali Imran, Ulul Albab ini kemudian diawali dengan 'Allah menyuruh kepada hambanya agar memperdalam keilmuan' dan di akhirnya Allah memberitahukan bahwa hanya orang-orang yang berpikirlah yang kemudian mampu mengambil pelajaran. Yang sebelumnya dalam redaksi ayat tersebut Allah menegaskan 'ar-rasikhuna fil ilmi' (orang-orang yang memperdalam ilmu). Dan pada ayat di surat Ali Imran yang lain, bahwa ciri orang yang beriman itu disetiap geraknya, tidurnya, dan apa-apanya pasti orang itu akan mengingat Allah. Dan itu adalah ciri-ciri orang-orang Ulul Albab..."

Dalam hal lain, Ulul Albab selalu dikaitkan dengan terminologi muhkamat dan mutasyabihaat. Sebagaimana diketahui bahwa dalam Al Quran terdapat dua jenis ayat, ayat muhkamat (yang jelas) dan mutasyabihaat (yang memerlukan takwil). Maka hanya Ulul Albab-lah yang mampu membongkar dan menggali makna dari ayat-ayat mutasyabihaat. Dan dari ke-16 ayat Ulul Albab selalu terselip kata kunci yang berkenaan dengan ilmu pengetahuan.

“...Kata kunci yang pertama dalam Ali Ilmran ayat 7, berkenaan dengan 'arrasikhuna fil 'ilmi'. Terkait...ayat muhkamat dan mutasyabihaat, siapa yang dapat memahami ayat mutasyabihaat (yang memerlukan penjelasan)? Ada yang berpendapat bahwa hanya Allah yang memahami ayat tersebut, namun ada pula yang berpendapat bahwa ayat tersebut dapat dipahami oleh orang yang rasikh dalam keilmuan yang dilanjutkan dengan kata-kata Ulul Albab. Kata kunci yang kedua, dalam Ali Imran ayat sekian (tidak ingat ayatnya), terkait alam semesta, tapi memang semua ayat Ulul Albab itu tidak terlepas dari kata kunci ilmu pengetahuan. Dari seluruh ayat Ulul Albab jika dikaji, semua pasti dilatarbelakangi ilmu pengetahuan..." 
Kata kunci selanjutnya, bahwa Ulul Albab selalu berkaitan dengan orang-orang yang selalu bersyukur, istiqomah dan pandai ber-dzikir untuk mentadabburi Al Quran dan alam ciptaan Allah.

“...kata kunci yang paling penting melatarbelakangi ayat-ayat Ulul Albab adalah perenungan-perenungan seorang manusia mengenai tanda-tanda alam yang harus dia baca...”.

Wawancara berikutnya adalah dengan mengajukan pertanyaan seputar definisi Ulul Albab menurut para narasumber. Mereka berpendapat diantaranya; Ulul Albab adalah orang yang mampu mengambil hikmah atau pelajaran di setiap peristiwa.

“...Ulul Albab adalah seseorang yang mampu mengambil hikmah atau pelajaran di setiap kejadian yang negatif ataupun positif..."

Selanjutnya Ulul Albab jika dilihat pada aspek bahasa terdapat kata Lubbun, yang dimaknai secara kontekstual bahwa seorang Ulul Albab mampu memahami sesuatu hingga aspek terdalam. Sehingga ketika seorang Ulul Albab berpikir, memahami, dan bergerak sampai ke akar-akarnya.

“... Sebetulnya persepektifnya bisa banyak, bisa meluas. Hanya memang jika dilihat pada aspek bahasa, Albaab itu kan berasal dari kata Lubbun, yang artinya itu intisari atau saripati. Jadi, mungkin bagaimana seseorang bisa lebih dalam dalam berpikir dan lebih dalam pula dalam memahami sesutau. Jadi intinya ketika memang tengah bergerak, berpikir dan memahami bisa hingga sampai ke akar-akarnya..."

“...Ulul Albab itukan artinya orang-orang yang berpikir. Maka kan dalam redaksi ayatnya itu selalu Allah memberikan redaksi agar orang-orang berpikir. Yaa.. itu artinya Allah menyuruh kita agar berpikir. Kita itu sudah diberikan akal, artinya pakailah akal itu sebaik-baiknya untuk memikirkan makna-makna pesan Allah yang tertera dalam kitab suci dan ciptaan-Nya..."

\section{c. Implementasi Indikator Ayat-Ayat Ulul Albab Kader Hima Persis STAI Persis Bandung Dalamkehidupan Sehari-Hari}

Untuk mengetahui seberapa jauh implementasi indikator ayat-ayat Ulul Albab tersebut dilakukan proses wawancara dan observasi. Wawancara dilakukan kepada 14 responden yang dianggap mewakili. Adapun observasi dilakukan selama kurun waktu bulan April hingga Juni.

Dalam mendeskripsikan hasil penelitian implementasi ayat-ayat Ulul Albab kader Hima Persis STAI Persis Bandung, penelitian difokuskan pada indikator yang sudah ditetapkan secara terukur dan terarah berdasarkan hasil elaborasi dari beberapa mufasir yang menafsirkan ayat-ayat Ulul Albab. Observasi ini adalah dengan memperhatikan keseharian kader Hima Persis STAI Persis Bandung yang menyangkut ibadah-ibadah kepada Allah sebagaimana yang dikemukakan dalam redaksi yang berkaitan dengan Ulul Albab. Berdasarkan hasil observasi terhadap kader Hima Persis STAI Persis Bandung yang dilakukan pada tanggal 16 Mei hingga 15 Juli, penyampaian hasil observasi sesuai dengan indikator yang ditetapkan dan dapat dianalisis oleh metode observasi. Maka dapat disampaikan sebagai berikut, diantaranya: 


\section{Upaya Menghindari Kemaksiatan}

Pada observasi yang dilakukan pada bulan Mei tanggal 16 hingga Juli tanggal 25, mengenai upaya untuk menghindari kemaksiatan, dapat dilihat bahwa kader Hima Persis STAI Persis Bandung selalu memiliki upaya untuk menghindari kemaksiatan. Hanya pada beberapa aspek, misal: masih ada beberapa kader yang masih sulit dalam menjaga jarak dengan kader Himi Persis atau mahasiswi lain. Baik dalam diskusi ataupun berbincang dimanapun.

\section{Sholat di Awal Waktu}

Untuk point tersebut berdasarkan hasil observasi yang dilakukan bahwa hampir terdapat sekitar 40\% kader Hima Persis STAI Persis Bandung melakukan sholat di awal waktu, baik yang dilaksanakan di masjid, di kosan, ataupun dirumahnya masing-masing.

\section{Tidak Berkata Kotor}

Untuk point tersebut berdasarkan hasil observasi yang dilakukan, menunjukan bahwa terdapat sekitar 30\% kader Hima Persis STAI Persis Bandung yang tergolong "parah" dengan standar yang ditetapkan; hampir setiap obrolan terdapat kata-kata kasar, kemudian hampir sekitar $40 \%$ tergolong "biasa-biasa" saja, dan hampir $40 \%$ tergolong berbahasa halus.

4. Empati terhadap Penderitaan Orang Lain

Berdasarkan hasil observasi yang dilakukan, menunjukan bahwa kader Hima Persis STAI Persis Bandung memiliki empati yang baik terhadap penderitaan kader dan orang lain. Dibuktikan dengan kepedulian kader terhadap beberapa kader yang lain yang mengalami beberapa masalah seperti sakit, kesulitan biaya kuliah, dan lain-lain.

5. Melaksanakan Tahajud

Berdasarkan hasil observasi, dalam melaksanakan tahajud, kader Hima Persis STAI Persis Bandung hanya sebagian terkecil dari jumlah keseluruhan kader. Satu ataupun dua kader yang melaksanakannya. Selain hanya sebagian kecil saja yang melaksanakan tahajud sesekali, kader Hima Persis STAI Persis Bandung kesulitan bangun tepat waktu untuk melaksanakan sholat subuh.

Setelah melakukan observasi, peneliti melakukan wawancara terhadap 14 narasumber. Pertanyaan wawancara meliputi hal-hal yang ditetapkan dalam indikator konkret diatas yang dibagi menjadi dua aspek, yakni aspek dzikir dan fikr. Aspek dzikir meliputi aktivitas-aktivitas peribadahan spiritual dan aspek fikr meliputi kegiatankegiatan intelektual akal.

Pada aspek dzikir, hasil wawancara yang dilakukan terhadap 14 responden, berdasarkan indikator yang ditetapkan menunjukan bahwa:

1. Hapal Minimal 13 dari 16 Ayat Ulul Albab

Hasil wawancara terhadap 14 responden, dapat diketahui bahwa tidak ada kader Hima Persis STAI Persis Bandung yang mampu hapal terhadap minimalnya 13 ayat dari 16 ayat Ulul Albab. Dari 14 responden yang diwawancarai 5 kader hapal sebanyak 2 ayat, 4 kader hapal sebanyak 1 ayat, dan 5 kader tidak hapal satu pun ayat Ulul Albab.

2. Melaksanakan Sholat di Awal Waktu 
Hasil dari wawancara yang dilakukan, dapat diketahui bahwa hanya $30 \%$ yang melaksanakan sholat di awal waktu, 40\% menyatakan "kadang-kadang", dan 30\% menyatakan "jarang".

\section{Tidak Berkata Kotor}

Hasil dari wawancara, semua kader Hima Persis STAI Persis Bandung memiliki upaya untuk tidak berkata kotor. Namun, menurut beberapa pengakuan, kader merasa sulit karena sering bergabung dengan kader-kader Hima Persis lainnya. Dan menurut beberapa pandangan narasumber lain, bahasa-bahasa yang dinilai "kotor" tersebut merupakan simbolisasi dari kedekatan dan tidak adanya sekat antar kader satu dengan kader lainnya.

4. Rutin Melaksanakan Tahajud

Hasil dari wawancara, hampir $100 \%$ atau keselruhan kader Hima Persis STAI Persis Bandung jarang atau tidak rutin melaksanakan shalat tahajud. Berdasarkan pengakuan para narasumber, hal tersebut disebabkan tidur yang terlalu larut malam dan alasan yang paling fundamental adalah kadar keimanan yang seringkali menurun sehingga menyebabkan kurangnya niat untuk melaksanakan hal tesebut.

5. Membaca Al Quran Minimal 1 lembar/hari

Hasil dari wawancara yang dilakukan, terdapat 70\% kader Hima Persis STAI Persis Bandung membaca Al Quran satu lembar per hari dan 30\% kader lainnya mengaku tidak melakukannya secara rutin satu lembar dalam sehari.

6. Mempelajari Hadits Nabi 1 Minggu Sekali

Hasil wawancara yang dilakukan, terdapat $20 \%$ yang melakukan kajian dan mempelajari hadits Nabi. Hal tersebut dilakukan lewat kajian-kajian yang dilakukan dalam halaqah-halaqah. Dan 80\% lainnya mengaku tidak mempelajari hadits Nabi secara rutin dalam 1 minggu sekali.

Dari hasil penelitian tersebut dapat diketahui bahwa masih sebagian kecil dari kader Hima Persis STAI Persis Bandung yang melakukan ibadah-ibadah intensif hasil dari representasi dzikir yang mencerminkan seorang Ulul Albab sesuai dengan indikator konkret yang dibuat diatas. Beberapa kader mampu bangun di sepertiga malam untuk melakukan ibadah-ibadah. Namun sebagian kader mengaku belum mampu melakukan hal tersebut.

“...kalau saya pribadi mungkin ada beberapa point yang bukan dzunnun bukan sering, tapi jarang juga, yaitu bangun ditengah malam dan bersahabat dengan alam, entah alam itu sendiri atau manusianya.. namun secara keumuman untuk kader Hima Persis, khususnya pada konteks di STAIPI Bandung, mungkin untuk beberapa hal ini sangat sedikit sekali yang mengerjakan. Mungkin karena beberapa hal yang menjadikan dirinya kemudian tidak melaksanakan hal-hal yang diserukan ayat-ayat Ulul Albab ini..."

“...jika dipersentasekan hanya ada 30\% yang bisa mengamalkan itu...kenapa saya katakana hanya 30\%? Karena kader Hima yang memiliki kesadaran sosial, individual, kesadaran terhadap alam, apalagi tentang rasa syukur terhadap Allah masih rendah..." 
“...alhamdulillah untuk diri saya pribadi, kita ambil contoh kecilnya saja; membuang sampah..(belum menemukan tempat sampah) itu saya simpan di saku, karena tidak ingin mencemari lingkungan. Terkhusus kalau kita misalnya membuang sampah kecil, kalaulah semua orang melakukan hal yang sama akan mengakibatkan banjir dan lain sebagainya..."

Selanjutnya pada aspek pikir atau intellect, yang meliputi hal-hal yang berkaitan dengan kemampuan berpikir dan kecerdasan intelektual seorang kader Hima Persis STAI Persis Bandung. Aspek pikir ini merupakan salah satu instrumen atau bagian dari indikator seseorang dipersonifikasikan sebagai Ulul Albab. Berdasarkan hasil observasi, kader Hima Persis STAI Persis Bandung cukup intensif untuk melatih kecerdasan intelektual mereka. Dilihat dari kajian-kajian yang kader adakan hampir setiap satu minggu sekali atau bahkan dalam satu minggu bisa dilaksanakan sebanyak empat atau bahkan lima kali.

Tema-tema kajian yang diadakan seputar tema terkait, filsafat, sosial, politik, ekonomi, dan lain-lain. Selain itu kader Hima Persis STAI Persis Bandung ini pun sering membuka lapak baca untuk melakukan kegiatan membaca bersama setiap hari selama masa kuliah. Pada waktu-waktu senggang, diluar kajian formal, kader Hima Persis STAI Persis Bandung pun sering mengadakan diskusi-diskusi di warung kopi bersama kader, mahasiswa lain, dan senior-seniornya di Hima Persis. Hal tersebut memperlihatkan intensitas yang cukup tinggi di tengah kader Hima Persis STAI Persis Bandung dalam melatih kecerdasan intelektualnya. Hasil observasi ini didukung oleh beberapa hasil wawancara dengan beberapa narasumber, yang mengutarakan bahwa:

1. Membaca Buku Minimal 60 halaman/hari

Dari hasil wawancara yang dilakukan, terdapat 50\% kader Hima Persis STAI Persis Bandung mampu membaca buku hingga 60 halaman per hari. Dan 50\% lainnya tidak sanggup secara rutin membaca 60 halaman per hari, hanya 20-40 halaman saja per hari. Hal tersebut dikarenakan kesibukan dan semangat yang naik turun.

2. Mengikuti Halaqah Diskusi 3x Dalam Seminggu

Berdasarkan hasil wawancara, $80 \%$ kader Hima Persis STAI Persis Bandung mampu mengikuti halaqah diskusi 3x dalam seminggu. 20\% kader lainnya hanya mampu mengikuti diskusi 1-2x saja, hal tersebut disebabkan kesulitan akses terhadap halaqah, semangat yang masih rendah, dan kesibukan-kesibukan kader.

"... saya sendiri sudah, namun belum istiqomah. Itu yang menjadi kekurangan dari diri saya...dan secara komunal pun alhamdulillah sudah..."

“...kalau menurut saya, kader Hima Persis pada aspek pikir khususnya berkaitan dengan daya kritis, itu diatas rata-ratalah..diatas rata-rata mahasiswa yang lain..."

“... sejauh ini kader Hima Persis (STAI Persis Bandung) sudah melakukan prosesproses tersebut, seperti baca buku, diskusi, menulis dan sebagainya..."

Menurut salah satu narasumber, Fakhri, bahwa implementasi pikir yang ada dalam internal kader Hima Persis STAI Persis Bandung harus dapat menyentuh wilayah praksis. Wilayah praksis ini diejawantahkan dan disosialisasikan pada masyarakat secara komunal. 
“...Aspek pikir ini pada sebagian hal masih belum terlalu mendalam hanya sebatas pada ruang-ruang diskusi saja...namun pada aspek praktis ke lapangan masyarakat masih terlihat kurang...karena kader Hima Persis ini harus mampu menjadi dinamo dalam masyarakat..."

Pada aspek pikir ini beberapa kader mengkonfirmasi bahwa memang aspek intelektual cukup kuat karena memang hal tersebut senada dan sejalan dengan visi Hima Persis secara global dan tradisi yang berkembang di Hima Persis STAI Persis Bandung dari tahun ke tahun.

“...kalau pada aspek pikir sudah. Karena itu sejalan dengan visi dan tradisi yang berkembang di Hima Persis (STAI Persis Bandung). Jika konteksnya adalah Hima Persis yang pernah saya diami memang lebih didominasi oleh aspek pikir ketimbang aspek dzikir..."

"Untuk saya pribadi belum secara seutuhnya untuk melaksanakan hal itu. Terlebih kalo misalkan dalam kaitannya dengan membaca Al Quran, mendalaminya secara dalam. Masih sangat-sangat sedikit untuk melihat kedalaman ayat-ayat..."

Dari beberapa kader Hima Persis STAI Persis Bandung yang diwawancarai, ada yang mengutarakan bahwa implementasi pikir dan melatih kecerdasan intelektual dalam indikator Ulul Albab cukup terlaksana, namun pada aspek ini justru terdapat kesalahan karena kader dinilai sering menggunakan kecerdasan intelektualnya untuk menyerang dan menjatuhkan argumentasi orang lain dalam setiap diskusi. Narasumber pun memandang bahwa moralitas atau adab kader kurang diperhatikan.

“...Kalau secara penilaian hari ini belum, mereka belum bisa mengimplementasikannya. Apalagi jika berbicara hikmah yang sering didefinisikan filsafat. Kader hanya mempelajari filsafat secara teoritis, tidak diterapkan pada wilayah-wilayah sosial dan cenderung menggunakan argumentasi filsafatnya untuk menyerang dan mematahkan argumentasi orang lain (dalam berdiskusi) untuk itu artinya adab dalam berilmu harus lebih diutamakan..."

Dari hasil observasi dan wawancara ditemukan bahwa ternyata terdapat ketimpangan antara proses dzikir dan pikir. Pada aspek dzikir ditemukan bahwa ternyata sebagian besar kader belum dapat mengimplementasikan sesuatu yang merepresentasikan Ulul Albab sebagaimana tertera dalam redaksi-redaksi ayat. Namun pada aspek pikir yang meliputi kecerdasan intelektual ditemukan bahwa kader Hima Persis cukup masif dan kuat. Hal tersebut mengindikasikan adanya ketimpangan yang cukup serius, data tersebut dikonfirmasi oleh sebagian kader sebagai berikut;

“...dalam mengkaji hal-hal yang berkaitan dengan Ulul Albab mereka (kader Hima Persis STAI Persis Bandung) sangat semangat, namun dalam pengaplikasiannya mereka sangat kurang..."

“...kader surplus pada aspek pikir namun defisit pada aspek dzikir, hal tersebut hanya perlu diseimbangkan, intinya jika misalkan dia kuat pada aspek pikir maka mesti dikuatkan oleh aspek dzikir, hal tersebut mesti dibangun oleh setiap individu kader Hima Persis STAI Persis Bandung..." 
“...menurut saya belum sepenuhnya, karena harus menyatukan aspek dzikir dan pikir...dan itu belum terlaksana dari sebagian besar (jumlah) kader..."

"...pandangan subjektif saya berdasarkan keseharian, kader belum dapat menyeimbangkan kedua aspek tersebut, lebih banyak pada aspek pikirnya daripada aspek dzikirnya. Karena memang bacaan-bacaannya pun diarahkan kesana, dan bacaan-bacaan pada aspek dzikir kurang..."

“...kader Hima Persis (STAI Persis Bandung) hari ini masih belum dapat menyeimbangkan kedua aspek tersebut (dzikir dan pikir). Lebih Tarik ke pikir tapi ketika area dzikir justru kadang kala terkalahkan oleh aspek pikir..."

Menurut Fakhri, ketimpangan antara aspek dzikir dan aspek pikir ini cukup signifikan. Pada proses pelatihan pola pikir seorang kader Hima Persis mampu tidak tidur hingga larut malam, namun ketika memasuki waktu shubuh justru malah bangun kesiangan. Dalam pandangannya, suatu program yang sulit untuk direalisasikan bisa jadi dipengaruhi oleh aspek dzikir yang kurang ditekuni oleh seorang kader, karena kader terlalu banyak didominasi melatih aspek pikir semata.

“...di satu sisi saya suka, di satu sisi saya kurang suka, kajian nyampe malam kan kuat, tapi ketika mau shubuh justru ko susah...yang menjadi kekahwatiran saya justru ketika Hima Persis (STAI Persis Bandung) mengalami kesulitan untuk melakukan program kerja atau apa yang dicita-citakan itu bisa jadi karena dzikirnya yang memang kurang..."

Dari ketimpangan yang ditemukan tersebut, beberapa kader mengemukakan bahwa kader-kader harus mengevaluasi hal tersebut agar bisa diseimbangkan. Evaluasi dan kritik yang disampaikan oleh para narasumber disampaikan kepada kader lain dan organisasi secara kelembagaan, karena menurut sebagian kader ketimpangan ini bukan hanya masalah individu melainkan dampak sistemik dari organisasi;

“...berdasarkan referensi spiritual yang saya baca, jika masalah semacam ini ditemukan, kalau kita shalat pada awal waktu maka akan dipermudah. Maka yang pertama harus mulai dicoba dengan memperbaiki shalat, baru setelah itu bar uke pikir..."

"...mungkin yang dirasakan sampai saat ini adalah pendalaman dan pentadabburan ayat-ayat terhadap Ulul Albab, kemudian seharusnya dibarengi dengan kajian relijiusitasnya harus ditekankan lagi, karena memang kajian yang disodorkan (ayat-ayat Ulul Albab) sedikit sekali..yang akhirnya mungkin kurang seimbang dan pengaplikasiannya menjadi kurang.

“...yang perlu dibenahi, dari aspek literasi, karena kan Hima Persis sering menggaungkan literasi, lebih dipahamkan saja bahwa tidak hanya aspek kognisi semata tapi mesti lebih diarahkan kepada hal-hal yang bisa berefek pada aspekaspek peribadahan. Selama ini Hima Persis lebih cenderung kepada aspek-aspek pemahaman, tapi aspek-aspek yang lebih praktis sangat minim...adapun secara kelembagaan sebetulnya cita-cita Hima Persis sudah sangat luhur, cuman memang orang-orang yang ada dalam Lembaga ini harus membaca lagi...' 
Salah satu narasumber mengutarakan bahwa ketimpangan itu terjadi disebabkan oleh pemahaman kader mengenai ayat Ulul Albab belum dikaji secara keseluruhan, hanya baru mengkajinya surat Ali Imron ayat 7 saja. Sehingga seharunnya dikaji secara keseluruhan yang berjumlah 16 .

“...bagi saya di Hima Persis (STAI Persis Bandung), kurang mengkaji ayat-ayat Ulul Albab karena banyak yang diketahui hanya surat Ali Imron ayat 7 saja, kurang mengkajinya secara keseluruhan..."

“...secara pribadi kader, selain kita membaca buku (umum) dan realitas, kita juga harus kembali lagi membaca kepada sumber ajaran agama yaitu Al Quran dan Sunnah...karena jika kita lepas dari itu semua hidup akans sesuai dengan apa yang dibacanya... dan lebih diintensifkan lagi dengan kajian yang dikolaborasikan dengan pengajian-pengajian yang dari dulu telah dibangun oleh ulama-ulama Persis, karena itu kultur yang melahirkan Persis itu sendiri..."

\section{Penutup}

Berdasarkan pertanyaan penelitian, penelitian ini fokus pada Ulul Albab sebagai pandangan hidup kader Hima Persis, dengan pendekatan fenomenologi terhadap pemahaman kader Hima Persis STAI Persis Bandung terhadap falsafah gerakannya, yakni ayat-ayat Ulul Albab. Hal tersebut meliputi pemahaman dan implementasi kader Hima Persis STAI Persis Bandung terhadap ayat-ayat Ulul Albab yang dijadikan sebagai ideologi/worldview bagi gerakannya.

Setelah melakukan penelitian terkait pemahaman kader Hima Persis STAI Persis Bandung terhadap ayat-ayat Ulul Albab dan implementasinya, maka peneliti menarik kesimpulan:

Pada aspek pemahaman terhadap pemaknaan atau definisi Ulul Albab, hampir semua kader Hima Persis STAI Persis Bandung mampu memberikan pandangannya untuk mendefinisikan Ulul Albab. Secara garis besar, menurut mereka Ulul Albab adalah orang yang mampu berpikir secara radikal hingga ke akar-akarnya dan mampu mengambil hikmah dari setiap kejadian yang dihadapinya. Ada dua dimensi yang membangun Ulul Albab, yakni dimensi dzikir dan pikir. Dan hanya seorang Ulul Albablah yang mampu menyeimbangkan kedua dimensi tersebut.

Dalam mengimplementasikan pemahamannya tentang ayat Ulul Albab, kader Hima Persis STAI Persis Bandung lebih didominasi pada aspek fikr (kegiatan-kegiatan yang bersifat intelektual) daripada aspek dzikir (kegiatan-kegiatan yang bersifat spiritual). Kader Hima Persis STAI Persis Bandung lebih menguatkan aspek pikirnya, hal tersebut terbukti dari beberapa kebiasaan yang dibangun kader melalui budaya-budaya diskusi, membaca, dan menulis yang lebih digelorakan. Namun pada aspek yang menyangkut dzikir kader Hima Persis STAI Persis Bandung dinilai lemah, dibuktikan dengan salah satu contoh kecilnya; kader Hima Persis STAI Persis Bandung sering telat dalam melaksanakan sholat shubuh, sementara dalam melakukan diskusi dan membaca bisa hingga larut malam. Atas ketimpangan yang ditemukan Hima Persis secara kelembagaan 
tidak dapat disalahkan karena Hima Persis secara kelembagaan justru telah mengangkat cita-cita besar yakni Ulul Albab. Yang perlu dievaluasi adalah kader-kader Hima Persis STAI Persis Bandung sendiri. Kader Hima Persis STAI Persis Bandung masih lemah pada aspek implementasi praksis di lapangan (masyarakat). Keunggulan pada aspek dzikirnya hanya dituangkan dalam bentuk-bentuk diskusi, membaca dan menulis. Aspek pikir yang dimiliki kader belum mampu dituangkan ke dalam gagasan konkret untuk masyarakat.

\section{Bibliografi}

Aliyah, Sri, Ulul Albab dalam Tafsir Fii Zilaalil Quran, JIA/Juni 2013/ThXIV/Nomor1/115-150,

II, Q. D. B. (2018). tentang Pimpinan dalam PP Hima Persis, Qanun Asasi-Qanun Dakhili Himpunan Mahasiswa Persatuan Islam.

IX, Q. D. B. (2015). Qanun Asasi-Qanun Dakhili Persatuan Islam; Penjelasan Qanun Asasi Qanun Dakhili Pedoman Kerja Rencana Jihad 2015-2020.

Moleong, L. J., \& Surjaman, T. (1991). Metodologi penelitian kualitatif. Penerbit PT Remaja Rosdakarya.

Pahala, Lam lam, Ulul Albab Falsafah Gerakan Kaum Intelektual, (Bandung: Hima Persis Pers), 2016.

Permana, A. (2017). Gerakan Mahasiswa.

Persis, T. K. dan P. S. P. H. (n.d.). Khittah Perjuangan Hima Persis dan Manajemen Pengelolaan Training.

Persis, T. K. dan P. S. P. H. (2018). Khittah Perjuangan Hima Persis dan Manajemen Pengelolaan Training.

Sanit, Arbi, Pergolakan Melawan Kekuasaan: Catatan Kritis Mahasiswa Antara Aksi Moral dan Aksi Politik, (Yogyakarta: Insists Press), 1999

Tim P3M STAI Persis Bandung. Pedoman Penulisan Karya Ilmiah STAI Persis Bandung. (Bandung: STAI Persis Bandung). 2018. 